\title{
Berebut Kuasa Tubuh: Norma Agama dan Kuasa Tubuh dalam Kekerasan Gender Berbasis Online
}

\author{
Rafif Pamenang lmawan \\ Peneliti Populi Center \\ ^Penulis Koresponden: raimwn@gmail.com
}

\section{ABSTRAK}

Kajian ini akan mengeksplorasi kekerasan berbasis gender dengan mengeksplorasi pengaturan data pribadi dan solusi dominasi patriarki dalam masalah media online. Dengan menggunakan tinjauan pustaka sistematis, tujuan dari penelitian ini adalah memberikan peta kompleksitas dalam masalah pemanfaatan media sosial online. Harapan dari penelitian ini adalah dapat memberikan informasi kepada pembaca tentang masalah hakikat kekerasan berbasis gender online dengan memberikan peta permasalahan sosial di Indonesia. Selain itu, secara akademis, tulisan ini akan mengeksplorasi teori postmodernisme tentang gender, ruang media sosial dan online serta masalah pola pikir struktural terkait kekerasan berbasis gender. Dalam ranah yang lebih praktis, tulisan ini akan memberikan landasan dasar bagi para pemangku kepentingan untuk merumuskan kebijakan terkait kekerasan berbasis gender secara online.

Kata Kunci: Kekerasan berdasarkan gender; online; media sosial; post-modernisme; patriarki

\section{ABSTRACT}

The COVID-19 forces people to isolate themselves to prevent the spread of the virus. COVID-19 increases the online activities of individuals to meet all their needs and obligations. Not only service-based applications that increased user activity, but also social media applications, which is Twitter. With the various features that Twitter offers, it not only makes it easier for individuals to communicate with people they know, but also opens up opportunities to interact with other users without any restrictions. Twitter allows its users to upload selfies and allows other users to comment on those selfies/uploads. In this research, authors analyzed sexually comments on @dododid_selfies during the 2020 period. Using Norman Fairclough's critical discourse analysis method, authors found 3 major discourses related to selfies of men with feminine gender expression, that are beautiful discourse $=$ women, objectification discourse and stigma and stereotypes. Through this study the author also found that online-based gender violence can be experienced by anyone in various forms.

Kata Kunci: Violence based on gender; online; social media; post-modernism; patriarchy

\section{PENDAHULUAN}

Perkembangan teknologi informasi tentu berdampak pada perubahan relasi sosial maupun ekonomi. Dalam banyak hal, perkembangan ini juga membawa banyak pengaruh positif sekaligus negatif pada saat yang bersamaan. Dari aspek ekonomi, perkembangan ekonomi dapat dipacu dengan cepat melalui jual beli online, gagasan dapat tersebar luas melalui media sosial, pun demikian dengan persoalan-persoalan yang menyangkut kekerasan berbasis gender (KBG). Sayangnya, perkembangan teknologi informasi sebatas wadah. Sebagai wadah interaksi baru, perkembangan teknologi informasi dalam hal ini media sosial, justru menjadi wadah yang tidak kalah problematik. Di dalam media sosial, orang dapat dengan mudah memalsukan identitasnya, membuat identitas yang tidak dapat dilihat oleh orang lain, termasuk ketika membicarakan hal-hal yang sensitif. Hal ini dalam beberapa hal positif, beberapa ilmuwan sosial bahkan melihat 
perkembangan media sosial ini dikaitkan dengan langkah-langkah politis baru, seperti revolusi yang ada di Mesir (Ghonim, 2012) ${ }^{1}$.

Problema yang tidak kalah akut terdapat pada persoalan gender. Tidak hanya kekerasan berbasis gender dalam dunia nyata yang menjadi masalah, dalam banyak hal, anonimitas dalam media sosial memungkinkan kekerasan gender berbasis online (KGBO) dapat dilakukan. Terlebih di masa pandemi COVID-19, ketika penyebaran virus COVID-19 membawa banyak dampak sosial bagi masyarakat, termasuk juga pengangguran yang bertambah, kondisi ekonomi yang sulit, hingga meningkatnya KBG. Di sisi yang lain, pandemi COVID-19 meningkatkan penggunaan media online sebagai instrumen utama dalam transaksi. Banyak usaha kecil dan menengah yang dipaksa untuk dapat beralih ke media online, termasuk transaksi digital. Hal ini yang kemudian menjadi catatan tersendiri dari SAFENet dan ELSAM. Ketika perlindungan terhadap data pribadi masih minim di Indonesia, termasuk masih belum adanya UU yang mengatur tentang hal ini.

Dalam hal apa pun, perkembangan teknologi informasi pada dasarnya menekankan kita sebagai subyek untuk menyetujui banyak hal, termasuk memberikan data-data pribadi kita. Pada media sosial, domain interaksi telah banyak berubah. Apabila dalam interaksi fisik, kita baru mengenal individu tersebut ketika bertatap muka, maka dalam media sosial, kita dapat mengetahui orang tersebut tanpa harus berinteraksi tatap muka. Dalam beberapa hal, bahkan kita membuka diri bagi orang lain untuk berkomentar terhadap banyak hal yang bersifat pribadi. Dalam media sosial, domain antara ranah pribadi dan ranah publik menjadi kabur. Secara tidak sadar kita juga membagikan momen pribadi melalui media sosial masing-masing.

Perubahan ruang tidak dapat dihindarkan dalam pembahasan terkait dengan KGBO. Perubahan ruang dari fisik ke digital memiliki banyak sekali konsekuensi, terutama sekali konsekuensi berkaitan dengan anonimitas dan dampak yang lebih luas dari kekerasan verbal, utamanya kepada perempuan dan anak-anak. Pokok persoalan yang kedua ada pada persoalan budaya, bahwa pada dasarnya KGBO merupakan cermin dari KBG dalam dunia non-digital. Persoalan ini menjadi pekerjaan rumah yang panjang, terutama bagaimana supaya dari sisi kultural, masyarakat tidak serta-merta melakukan pelecehan sosial. Bagaimana pun relasi patriarki di dunia media sosial, merupakan cerminan dari relasi patriarki di dunia sosial. Dalam dunia media sosial, kita tidak lagi memiliki kuasa terhadap tubuh kita, ketika persoalan privasi menjadi hal yang sangat mahal di dunia media sosial.

Terdapat dua hal yang menarik untuk dilihat, terkait bagaimana pengaturan data pribadi dan bagaimana solusi agar dapat membuat relasi patriarki tidak dominan dalam persoalan di media

\footnotetext{
${ }^{1}$ Dalam catatannya, Ghonim melihat bagaimana narasi terkait dengan revolusi di Mesir dibangun dengan cara media sosial yang secara masif memberitakan bagaimana pemuda Mesir mendapatkan kekerasan dari tentara. Kekerasan ini kemudian membuat banyak warga masyarakat marah dan mengakibatkan terjadinya revolusi sosial. Media sosial memegang peranan penting dalam konteks ini. Lihat: Ghonim, W. 2012. Revolution 2.0: The power of the people is greater than the people in power: A memoir. Houghton Mifflin Harcourt
} 
online. Secara praktis, diharapkan tulisan ini dapat sedikit memperkaya kajian yang telah ada, khususnya berkaitan dengan KGBO.

\section{TINJAUAN PUSTAKA}

Bahasan terkait dengan kekerasan online terbagi ke dalam beberapa kategori. Paling tidak terdapat tiga kategori besar dari diskursus yang ada, yakni kekerasan gender dengan Islam, Kekerasan berbasis gender (KBG), dan Kekerasan Berbasis Gender Online (KGBO).

\section{Islam dan Kekerasan Gender}

Bagi sebagian kasus, kekerasan berbasis gender menunjukkan ada keterkaitan dengan agama. Dari beberapa diskursus terkait, pada konteks ini, agama Islam menjadi salah satu yang menarik perhatikan ketika dihubungkan dengan kekerasan gender, sebagaimana beberapa studi tentang hal tersebut.

Pada bagian pertama ini, yang ditunjukkan adalah keterkaitan antara ekstremisme dengan kekerasan gender. Dari studi Curtis (2020), misalnya, kita dapat melihat bagaimana perempuan dengan mudah masuk ke dalam ranah ekstremisme. Banyak media yang menyebabkan terjadinya hal tersebut, salah satunya adalah media, yakni telegram dan beberapa media lain. Masuk ke dalam ranah tersebut bagi Curtis merupakan sebentuk fenomena tentang bagaimana perempuan menjadi bagian ekstremisme dengan tanpa adanya konteks sosial-budaya dan halangan agama (Curtis, 2020). Dalam proses rekrutmen ekstremis perempuan, narasi yang paling banyak dibawa adalah anti negara barat. Melalui narasi ini, maka dominasi patriarki dalam propaganda rekrutmen wanita ekstremis dapat dikaburkan (Johnston, et al, 2020)

Pada studi yang berbeda, Aly dan Thoyibi (2020) melihat bahwa terdapat pengajaran yang berbeda terkait dengan perdamaian, terutama pada bahan ajaran terkait dengan dua organisasi besar Islam di Indonesia, yakni Muhammadiyah dan Nahdlatul Ulama (NU). Kedua organisasi ini menggunakan cara yang berbeda untuk menekankan pentingnya perdamaian, Muhammadiyah menekankan perdamaian dengan demokrasi dan hak asasi manusia (HAM), sedangkan NU menekankan pada kepentingan sosial dan bangsa. Dalam konteks melawan ekstrimisme, maka kedua pendekatan ini perlu untuk digabungkan (Aly \& Thoyibi, 2020). Pada studi lain, tafsir agama dan budaya patriarki sering kali menjadi dua kombinasi utama sebagai motif kekerasan berbasis gender (Sofiani, 2013).

Pada studi yang berbeda menunjukkan bagaimana paska reformasi, gerakan perempuan semakin ter polarisasi, terutama berkaitan dengan isu dengan pengaruh global hingga keterlibatan dalam organisasi. Dalam isu terkait dengan poligami misalnya, kelompok perempuan terbagi menjadi dua, yakni kelompok yang menentang dengan pengaruh liberalisme dan feminisme, serta kelompok kedua yang menggunakan pendekatan Islam. Paska reformasi, keterlibatan perempuan dalam organisasi turut mendorong penguatan diskursus (Rinaldo, 2011).

Persoalan gender dan agama semakin meruncing, terutama berkaitan dengan lesbian, gay, biseksual, dan transgender (LGBT). Dalam studi yang dilakukan oleh Davies \& Robert (2018), 
Indonesia memiliki beberapa budaya dan peran sosial yang berada pada posisi antara laki-laki dan perempuan. Peran tersebut ada dalam posisi dukun (shaman) dalam masyarakat Bugis. Dalam pandangannya, pernyataan Presiden Joko Widodo di tahun 2016 bahwa tidak ada ruang bagi kelompok LGBT menjadi tidak relevan, terutama mengingat dari aspek kultural, terdapat budaya LGBT di Indonesia. Baginya sikap Presiden disebabkan oleh desakan dari kelompok Islam dalam pemerintahan (Davies \& Robert, 2018). Terutama sekali untuk dapat menjaga dominasi moralitas. Paska reformasi, muncul beberapa sentimen terhadap gerakan homofobia. Sentimen-sentimen ini tidak muncul pada masa pemerintahan orde baru, paska orde baru sentimen ini menguasai ruangruang publik yang ada (Boellstorff, 2004)

\section{Kekerasan Berbasis Gender (KBG)}

Dalam situasi konflik, perempuan selalu menjadi kelompok yang rentan. Terutama berkaitan dengan reproduksi sosial, mata pencaharian, dan partisipasi di masyarakat. Perempuan memiliki peran yang krusial dalam situasi konflik, terutama apabila menggunakan pendekatan agensi dan menempatkan perempuan sebagai agen untuk mengatasi konflik komunal, seperti pengalaman di Aceh, Ambon, dan Papua ${ }^{2}$ (Yasya, 2018). Dalam studi yang berbeda, studi terkait dengan penegakan hukum terhadap kekerasan seksual menunjukkan bahwa dalam upaya penegakannya, terdapat bias kultural dalam proses penegakkan hukum pada kasus kekerasan seksual. Hal ini disebabkan oleh dominasi dari budaya patriarki yang kuat (Asmarany, 2007), termasuk dalam penegakan hukum (Rahayu, et al, 2017). Problema yang rumit juga ada pada kasus kekerasan seksual pada anak, studi yang ada menunjukkan bagaimana sulitnya mengakses data terkait dengan kasus ini di Indonesia. Hal ini terutama berkaitan dengan norma sosial yang melekat kuat di masyarakat, termasuk keterbukaan korban, bagaimanapun juga isu kekerasan seksual pada anak merupakan isu sensitif (Rumble, et al, 2020). Persoalan lain ada pada sulitnya melakukan pengukuran kekerasan seksual pada anak, mengingat sensitifnya isu ini (Rumble, et al, 2018).

Persoalan gender berkaitan pula dengan bagaimana perubahan kekuasaan. Perubahan dari sentralisasi kekuasaan (otoritarianisme) menuju ke desentralisasi kekuasaan (demokrasi) di Indonesia mendorong perubahan wacana dalam ruang publik. Perubahan wacana yang sangat terlihat ada pada diskursus terkait dengan moralitas, terutama berkaitan dengan moralitas dan identitas. Identitas yang berbenturan seperti identitas agama dan orientasi seksual menjadi semakin ramai diperbincangkan di tingkat daerah, hingga beberapa daerah memutuskan untuk menerapkan aturan daerah yang mengatur hal tersebut. Secara umum, terdapat penekanan yang lebih kuat pada dimensi moralitas dibandingkan masa-masa sebelumnya, termasuk di ruang publik, politik formal, institusi pemerintah, hingga kehidupan keseharian (Platt, et al, 2018).

Dominasi kajian gender yang lain ada pada isu terkait dengan kekerasan domestik. Dalam studi yang dilakukan Nur Hayati, et al (2013) di Purworejo, hasil dari beberapa wawancara

\footnotetext{
${ }^{2}$ Penekanan perempuan sebagai agen perdamaian telah masuk dalam regulasi yakni Peraturan Presiden (Pepres) no 18/2014 tentang proteksi terhadap perempuan dan anak dalam konflik sosial. Pendekatan agensi dengan menekanka pada perempuan, diharapkan dapat mendorong transformasi sosial, terutama di wilayah konflik.
} 
menunjukkan satu hal yang menyulitkan perempuan keluar dari kekerasan domestik, yakni berkaitan dengan norma sosial. Meski telah terdapat dukungan internal maupun eksternal untuk mengatasi kekerasan yang dialaminya. Terdapat nilai sosial yang kuat di masyarakat bahwa perempuan memiliki kewajiban untuk menjaga keharmonisan keluarga (Nur Hayati, et al, 2013; Nur Hayati, et al, 2011).

Pada aspek yang lain, dalam penelitian United Nation Research Institute for Social Development (UNRISD) menunjukkan pentingnya penguatan gerakan perempuan, terutama untuk menciptakan kesetaraan gender dalam pembuatan kebijakan publik (Eddyono, et al, 2018). Pada studi yang berbeda, pandemi COVID-19 telah membawa banyak perubahan, terutama berkaitan dengan potensi kekerasan domestik. Dalam studi yang dilakukan oleh Irawaty (2020) menunjukkan bagaimana kekerasan domestik meningkat selama pandemi COVID-19. Hal ini relevan dengan bagaimana kekerasan domestik cenderung meningkat ketika terdapat bencana alam (Irawaty, 2020).

Pada kasus yang berbeda, Wuryaningsih, et al, (2017) mencatat bagaimana pemerintah kabupaten Banyumas belum memberikan dukungan penuh terhadap kehadiran Penyelenggaraan Perlindungan Korban Kekerasan Gender dan Anak (PPT PKBGA) yang terbit melalui Perda no 3/2015. Belum solidnya dukungan terhadap PPT PKBGA terlihat dari dukungan anggaran yang belum terpenuhi ke program tersebut (Wuryaningsih, et al, 2017). Pada konteks kota Makassar, kelemahan penanganan terhadap kekerasan berbasis gender ada pada kurang kuatnya penegakan hukum (Arief, 2018)

\section{Kekerasan Berbasis Gender Online (KGBO)}

Pada persoalan kekerasan gender berbasiskan online, studi yang dilakukan Christian (2020), studi ini menekankan bagaimana banyaknya praktik kekerasan berbasis gender yang dilakukan pelaku dengan memeras korban terlebih dahulu, baik secara materiil maupun seksual, disertai dengan ancaman dari pelaku untuk menyebarkan konten pornografi milik korban. Praktik ini diberi label sebagai sekstorsi, yakni melakukan pemerasan dengan cara mengambil data melalui hacking ${ }^{3}$ (Christian, 2020). Hal ini sedikit berbeda dengan konsepsi kekerasan gender dengan motif online grooming, pada kekerasan gender online grooming, maka dimensi psikologis dari perempuan yang coba dimanipulasi, termasuk dengan memberikan sanjungan dan pujian (Wahyuni, 2021). Sejak Komisi Nasional Perempuan membuka pendampingan KGBO, banyak sekali korban yang melaporkan diri. Hal ini menunjukkan bahwa selama ini terdapat kasus-kasus yang tidur dalam penganan KGBO (Illene, et al, 2019).

Kampanye terhadap KGBO telah banyak dilakukan. Salah satu studi yang ada mencoba untuk melihat bagaimana dampak dari kampanye "Awas KGBO!" yang dikampanyekan melalui media sosial Instagram. Hasil menunjukkan bahwa salah satu tantangan terbesar dalam kampanye ini ada

\footnotetext{
${ }^{3}$ Dalam studinya, kekerasan sekstorsi masuk ke dalam kategori pidana, seperti diatur dalam pasal 368 KUHP, dan Pasal 45 ayat (4), adapun apabila konten telah disebarkan, maka kasus tersebut masuk ke dalam Pasal 29 UU Pornografi dan Pasal 45 ayat (1) UU ITE (Christian, 2021).
} 
pada sisi advokasi gerakan yang semula online menjadi offline. Hasilnya menunjukkan bahwa meski banyak partisipasi dalam platform online, namun ketika masuk ke dalam gerakan offline, antusiasme tidak sebesar ketika berada dalam platform online (Ratnasari, et al, 2021). Pada penelitian yang lain, Ratnasari, et al, (2020) melihat bagaimana kampanye “Awas KGBO!” justru gagal menyampaikan gagasannya dikarenakan didominasi oleh fear appeals (daya tarik ketakutan). Pendekatan humanis dan menyasar ke orang tua justru menjadi cara yang lebih efektif untuk memberikan pesan anti kekerasan gender (Ratnasari, et al, 2020).

Pada ranah yang lain, persoalan diskriminasi terhadap perempuan cukup kuat berada pada media massa online. Dalam studi yang dilakukan Susilo (2017) menunjukkan bagaimana secara kultural terdapat dominasi maskulinitas dalam pemberitaan di Alexa.com dan Tribunnews.com yang keduanya dimiliki oleh Kompas Gramedia. Dominasi maskulinitas terdapat pada pemberitaanpemberitaan yang dilakukan oleh kedua media online tersebut (Susilo, 2017). Pada studi lain terkait dengan KGBO, dibutuhkan dua acara utama untuk mengatasi KGBO, yakni dengan upaya penal yakni keberadaan peraturan perundangan-undangan yang melindungi perempuan dari kekerasan berbasis gender online, serta upaya non-penal yakni dengan cara melakukan sosialisasi dan meningkatkan kesadaran KGBO (Prameswari, 2021).

\section{Hal yang belum Terjawab}

Melalui penelusuran Pustaka yang ada, belum ada elaborasi lebih lanjut mengenai bagaimana batasan peran negara, Non-Govermental Organization (NGO), maupun lembaga multinasional dalam menangani persoalan KGBO. Hal yang belum terjawab, sejauh mana usaha dari negara dilakukan, terutama bagaimana manajemen pengetahuan (knowledge management) dilakukan dari para pemangku kebijakan yang berkaitan dengan KGBO.

\section{KERANGKA PIKIR, METODOLOGI, DAN METODE}

Teori-teori modernisme gagal untuk menjelaskan bagaimana kekuasaan bekerja pada kelompok marginal. Pendekatan teorisasi yang menekankan pada modernisasi menekankan pada bagaimana kapasitas organisasi maupun individual dalam relasi sosial. Cara pandang ini kemudian menekankan bagaimana organisasi mengambil peran dalam persoalan terkait dengan kekerasan pada wanita, sedangkan dalam tataran individual, menekankan pada bagaimana organisasi seseorang melakukan tindakan rasional (Coleman, 1992; 1988). Dominasi pandangan modernisme ini berlaku pula pada cara pandang feminisme, baik feminisme liberal, maupun feminisme Marxisme. Relasi kuasa dari cara pandang ini ada pada domain kesetaraan hingga apakah dimungkinkan struktur untuk memberikan peluang bagi kesetaraan gender (Hay, 2005; Hooks, 2020).

Cara pandang dominan saat ini ada pada tradisi post-strukturalis. Hal ini terutama mengingat cara pandang strukturalis, dianggap tidak memadai dalam melihat dominasi. Dengan kata lain, relasi kuasa tidak dapat dilihat secara lebih memadai dalam kasus relasi kuasa gender. Cara pandang modernis juga banyak dikritik, oleh karenanya cara pandang post-modernis seperti dalam tokoh Michel Foucault banyak menjadi rujukan. Salah satu rujukan utama adalah konsepsi mengenai 
pengetahuan sebagai kekuasaan (Foucault, 2019), pandangannya terkait dengan tubuh, atau dikenal pula sebagai konsepsi mengenai biopolitics (Foucault, et al, 2008), hingga relasi kuasa dalam seks dan tubuh (Foucault, 1978). Konsepsi dari Michel Foucault terhadap bagaimana kekuasaan bekerja, menjadi cara pandang utama dalam melihat relasi digital, termasuk di dalamnya bagaimana data pribadi menjadi basis material baru untuk berkuasa. Kuasa digital terhadap tubuh ini, dalam konsepsi teorisasi terkait kuasa atas tubuh disebut dengan biopolitics 2.0 (Gabrys, 2014).

Persoalan KGBO pada dasarnya tidak dapat dilepaskan dari beberapa aspek, termasuk didalamnya berkaitan dengan data pribadi, peran para pemangku kebijakan, regulasi yang mengatur, hingga persoalan. Diantara banyak aspek tersebut, persoalan budaya yang dalam hal ini merujuk pada budaya patriarki merupakan persoalan yang paling lama penyelesaiannya. Dalam beberapa aspek, budaya dapat berubah ketika aturan atau struktur dibangun. Dalam konteks ini struktur yang dimaksud adalah instrumen hukum. Bagaimanapun juga, hukum mengatur mengenai norma. Oleh karenanya aturan hukum pada akhirnya akan merubah norma. Mekanisme pengarusutamaan isu ini, terutama berkaitan dengan aspek mengarusutamakan $\mathrm{KGBO}$, paling ideal dilakukan dengan cara melakukan konsorsium ataupun kaukus yang dapat mengelola pengetahuan di dalamnya dengan baik.

Pendekatan kebutuhan lembaga yang mengatur pengetahuan dengan baik ini, disebut dengan boundary organization. Konsep ini pada dasarnya menekankan pada pentingnya kemampuan dari lembaga, apakah itu permanen atau ad hoc, untuk dapat mengelola pengetahuan maupun konflik, agar dapat berpengaruh secara positif terhadap kebijakan publik (Gustafsson \& Lidskog, 2018). Pendekatan ini dekat dengan tradisi post-strukturalis, terutama ketika menekankan pada pentingnya manajemen pengetahuan. Pendekatan ini berbeda dengan pendekatan lama yang menekankan pada kapabilitas lembaga dalam mengatasi isu-isu non-dominan seperti gender (Guston, 2001).

Berdasarkan cara pandang ini, bagaimana pemangku kepentingan mencoba untuk melakukan manajemen pengetahuan terhadap isu KGBO. Terutama berkaitan pula dengan beberapa isu lain yang bersinggungan, terutama isu data diri, isu RUU penghapusan kekerasan seksual, hingga aktor-aktor yang terlibat. Apakah Indonesia telah melangkah maju dengan menggunakan manajemen pengetahuan sebagai basis untuk memperkuat sistem preventif KGBO, atau masih menggunakan cara lama.

\section{HASIL DAN PEMBAHASAN}

Hal paling krusial dari penanganan KGBO ada pada dimensi regulasi. Pada tahun ini, RUU Penghapusan Kekerasan Seksual (Pungkas) masuk dalam prolegnas 2021, atau RUU yang menjadi prioritas bagi Dewan Perwakilan Rakyat (DPR) RI. RUU Pungkas yang sebelumnya dikenal dengan RUU PKS menjadi salah satu aspirasi utama ketika gelombang demonstrasi menolak UU Cipta Kerja (Ciptaker) dilakukan. Demonstrasi di Jakarta hingga Yogyakarta menekankan pada 
penolakan dua RUU tersebut. Gejayan Memanggil, sebuah aksi di Yogyakarta misalnya, secara lantang menegaskan perlunya RUU Pungkas untuk disahkan (Republika, 10/03/2020).

Pada sisi yang berbeda, RUU Perlindungan Data Pribadi (PDP) menjadi salah satu RUU yang masuk dalam daftar Prolegnas tahun 2021 (Kompas, 23/03/2021). Adapun pembahasan UU ITE yang banyak dikritik karena mengandung banyak pasal karet, tidak jadi direvisi, meski sudah banyak dikritik hingga Presiden Joko Widodo sempat pula memberikan sinyal perlunya revisi atas UU tersebut (Kompas, 12/03/2021). RUU Pungkas yang menjadi basis utama untuk menjerat pelaku kekerasan seksual tidak dilakukan. Salah satu alasan utama ditolaknya pengesahan RUU Pungkas ada pada dominannya ideologi liberal dalam RUU Pungkas, hingga persoalan akan disalahgunakannya RUU tersebut dalam membawa isu LGBT. Salah satu partai yang secara keras menolak pengesahan RUU Pungkas adalah Partai Keadlian Sejahtera (PKS). Baginya pembicaraan mengenai kekerasan seksual harus diatur lebih detail lagi agar tidak melebar (Detik, 07/12/2019). Apabila ditinjau dari sisi ideologi, penolakan terhadap RUU Pungkas sangat dapat dipahami apabila kita melihat perbenturan utama antara nilai Islam dan perjuangan atas kekerasan gender. Hasil elaborasi Pustaka yang telah dilakukan menunjukkan bahwa bahasan terkait dengan nilai Islam dan kekerasan gender menjadi salah satu bahasan utama. Salah satu persoalan serius dari dominasi bahasan utama dari perspektif agama, ada pada hilangnya narasi otonomi atas tubuh. Padahal bahasan terkait dengan otonomi terhadap tubuh merupakan bahasan yang tidak dapat dilepaskan dari persoalan kekerasan gender. Cara pandang melalui agama menjadi cara pandang dominan, termasuk melakukan hegemoni terhadap cara mengatasi konflik rumah tangga (Sofiani, 2013). Domain publik dan privat bagaimanapun juga menjadi domain yang paling penting untuk diperhatikan, karena berkaitan dengan independensi dari individu.

Apabila dilihat dari kacamata norma dan pengetahuan, agama merupakan set of rules yang dapat masuk ke dalam ranah privat. Adapun dalam tradisi post-strukturalis, tubuh merupakan ranah privat yang dalam konteks Indonesia masih didominasi oleh negara. Hal inilah yang kemudian menjadikan persoalan kekerasan berbasis gender sangat ditentukan oleh struktur yang ada di wilayah tersebut. Yogyakarta misalnya, wilayah ini relatif dapat mengatasi persoalan kekerasan seksual dikarenakan banyaknya NGO yang berada di sana dan memberi perhatian lebih terhadap persoalan tersebut (Tardi, 2021). Paling tidak terdapat Rifka Anissa yang berfokus pada isu tersebut, termasuk kehadiran lembaga kajian di kampus, seperti Pusat Studi Wanita (PSW) UGM.

Pada tingkat nasional SAFEnet menjadi salah satu aktor yang secara aktif mendorong pengesahan RUU Pungkas (SAFEnet, 28/01/2021). Perhatian yang sama dilakukan oleh ELSAM, yang memberikan laporan berkala terkait dengan perkembangan RUU Pungkas (ELSAM, 12/10/2020). Apabila dilihat dari proses akumulasi pengetahuan, maka wilayah sangat menentukan akumulasi isu. Di DKI Jakarta misalnya desakan terhadap pengesahan RUU Pungkas dilakukan pula oleh Kaukus Perempuan Parlemen (Kompas, 12/08/2020). Akumulasi untuk isu terkait dengan RUU Pungkas, paling tidak terakumulasi pada banyak aktor, meliputi antara lain SAFEnet, ELSAM, Komnas Perempuan, dan Kaukus Perempuan Parlemen. Di Yogyakarta juga terbentuk simpul yang menjadi gerak dari RUU Pungkas, meliputi antara lain Rifka Annisa dan PSW UGM. 
Di beberapa wilayah, daerah telah memberikan perhatian, seperti di Banyumas yang membentuk PPT PKBGA. Hanya saja keberadaan NGO di wilayah tersebut nampaknya tidak banyak, hingga narasi terkait dengan KBG dan KGBO tidak terlalu dominan. Persoalan utama ada pada benturan klasik antara isu gender dan agama. Dalam kasus KGBO, dominan diskursus yang masuk ke dalam ranah individual adalah persoalan agama. Keduanya masuk ke dalam ranah privat, ketika agama masuk dalam sisi normatif, dalam diskursus feminisme kontemporer masuk pada dominasi/relasi kuasa hingga persoalan kuasa tubuh. Terkait dengan problem kultural, penegakan hukum secara tidak langsung akan mendorong pembentukan kultural perubahan budaya kesetaraan dibandingkan budaya patriarki.

\section{KESIMPULAN DAN REKOMENDASI KEBIJAKAN}

Pengesahan UU Pungkas merupakan syarat mutlak dari upaya mengatasi KBG dan KGBO. Poin terkait dengan KGBO yang semula tidak ada dalam RUU Pungkas versi lama, telah diberikan masukan oleh Komnas Perempuan untuk dimasukkan dalam rancangan RUU yang baru (Pikiran Rakyat, 26/03/2021). Hal lain yang perlu diperhatikan kesinambungan dengan RUU PDP hingga KUHP. Salah satu usaha yang tidak kalah penting adalah proses pengawalan pembahasan RUU Pungkas. Oleh karenanya pembentukan kaukus untuk mengawal isu ini menjadi penting. Utamanya berkaitan dengan manajemen pengetahuan. Tantangan terbesar barangkali ada pada bagaimana mencari jalan tengah antara aspirasi agama dan domain privat dalam RUU Pungkas. Kajian Pustaka menunjukkan bahwa benturan keduanya telah ada dalam beberapa waktu.

\section{DAFTAR PUSTAKA}

Buku

Coleman, J., \& Fararo, T. J., 1992. Rational Choice Theory. Nueva York: Sage

Foucault, M., Davidson, A.I., \& Burchell, G. 2008. The Birth of Biopolitics: lectures at the Collège de France, 1978-1979. Springer

Foucault, M. 1978. The History of Sexuality, Vol. 1: An introduction. Trans. Robert Hurley. New York: Pantheon

Foucault, M. 2019. Power: the Essential Works of Michel Foucault 1954-1984. Penguin UK

Ghonim, W. 2012. Revolution 2.0: The Power of the People is Greater Than the People in Power: A Memoir. Houghton Mifflin Harcourt

Hay, C. 2005. The State: Theories and Issues. Palgrave

Hooks, B. 2020. Feminis Untuk Semua Orang. Odeise Publishing

Jurnal

Aly, A., \& Thoyibi, M. 2020. Violence in online media and its implication to Islamic education of Indonesia. Indonesian Journal of Islam and Muslim Societies 10, no. 1 (2020)

Arief, A. 2018. Fenomena Kekerasan Berbasis Gender \& Upaya Penanggulangannya. PETITUM 6, no. 2 Oktober 2018: 76-86. 
Asmarany, A.I. 2007. Bias gender sebagai prediktor kekerasan dalam rumah tangga. Jurnal psikologi 35, no. 1:1-20.

Boellstorff, T. 2004. The emergence of political homophobia in Indonesia: Masculinity and national belonging. ethnos 69, no. 4 (2004): 465-486.

Christian, J.H. 2020. Sekstorsi: Kekerasan Berbasis Gender Online Dalam Paradigma Hukum Indonesia." Binamulia Hukum 9, no. 1 (2020): 83-92.

Coleman, J. S. 1988. "Social capital in the creation of human capital." American journal of sociology 94 (1988): S95-S120.

Curtis, G. 2020. "What Indonesia is Getting Wrong About Women and Violent Extremism." THC Insight, No. 18 / 11 June 2020

Davies, S.G., dan Hefner, R. 2018. "Gender and sexual plurality in Indonesia: Past and present." Routledge handbook of contemporary Indonesia. New York: Routledge.

Eddyono, S.W., et al. 2018. "When and why the State responds to women's demands: understanding gender equality policy change in Indonesia." United Nations Research Institute for Social Development.

Gabrys, J. 2014. "Programming environments: Environmentality and citizen sensing in the smart city." Environment and planning D: Society and space 32, no. 1 (2014): 30-48.

Gustafsson, K.M., dan Lidskog, R. 2018. "Boundary organizations and environmental governance: Performance, institutional design, and conceptual development." Climate Risk Management 19 (2018): 1-11.

Guston, D.H. 2001. "Boundary organizations in environmental policy and science: an introduction." (2001): 399-408.

Hayati, E. N., et al. 2011. "Behind the silence of harmony: risk factors for physical and sexual violence among women in rural Indonesia." BMC women's health 11, no. 1 (2011): 52.

Illene, A., Damajanti, M.N., dan Muljosumarto, C. 2019. "Perancangan Kampanye Sosial Mengenai Kekerasan Berbasis Gender Online." Jurnal DKV Adiwarna 1, no. 14 (2019): 10.

Irawaty, D.K. 2020. "Rumah Tidak Selalu Menjadi Surga: Krisis Kekerasan Dalam Rumah Tangga Berbasis Gender Saat Pagebluk COVID-19." In Prosiding Forum Ilmiah Tahunan (FIT) IAKMI. (2020).

Johnston, M.F., Iqbal, M., dan True, J. 2020. "The Lure of (Violent) Extremism: Gender Constructs in Online Recruitment and Messaging in Indonesia." Studies in Conflict \& Terrorism (2020): 1-19.

Hayati, E., et al, 2013. "'Elastic band strategy': women's lived experience of coping with domestic violence in rural Indonesia." Global health action 6, no. 1 (2013): 18894.

Platt, M., Davies, S.G., dan Bennett, L.R. 2018. "Contestations of gender, sexuality and morality in contemporary Indonesia." Asian Studies Review (2018): 1-15.

Prameswari, J.R.C, Hehanussa, D.J.A, dan Salamor, Y.B. 2021. "Kekerasan Berbasis Gender Di Media Sosial." PAMALI: Pattimura Magister Law Review 1, no. 1 (2021): 55-61.

Rahayu, N., et al. 2017. "Legal Policy of Sexual Violence in Indonesia." JL Pol'y \& Globalization 67 (2017): 174. 
Ratnasari, E., Sumartias, S., dan Romli, R. 2020. "Penggunaan Message Appeals dalam Strategi Pesan Kampanye Anti Kekerasan Berbasis Gender Online." Jurnal Ilmu Komunikasi 18, no. 3 (2020): 352-370.

Ratnasari, E., Sumartias, S., dan Romli, R. 2021. "Social Media, Digital Activism, and Online Gender-Based Violence in Indonesia." Nyimak: Journal of Communication 5, no. 1 (2021): 97-116.

Rinaldo, R. 2011. "Muslim women, moral visions: Globalization and gender controversies in Indonesia." Qualitative sociology 34, no. 4 (2011): 539-560.

Rumble, L. et al. 2018. "The importance of contextual factors in carrying out childhood violence surveys: A case study from Indonesia." Child indicators research 11, no. 2 (2018): 405-421.

Rumble, L. et al. 2020. "Childhood sexual violence in Indonesia: a systematic review." Trauma, violence, \& abuse 21, no. 2 (2020): 284-299.

Sofiani, T. 2013. "Tafsir agama dan kekerasan berbasis gender." Jurnal Penelitian 5, no. 2 (2013).

Susilo, D. 2017. "Masculinity discourse on media text: A critical review about news about violence on online news portals." Masyarakat, Kebudayaan dan Politik 30, no. 4 (2017): 344-352.

Wuryaningsih, T., Baharudin, N., dan Mutahir, A. 2017. "Advokasi korban kekerasan berbasis gender dan anak (studi kasus di kabupaten banyumas)." Prosiding 7, no. 1 (2017).

Yasya, W. 2018. "Gender Analysis of Communal Conflicts in Indonesia." In Proceedings of The International Conference on Social Sciences (ICSS), vol. 1, no. 1. (2018).

Artikel Online

Detik, 7 Februari 2021, Ini Sederet Alasan F-PKS Tolak RUU Penghapusan Kekerasan Seksual, https://news.detik.com/berita/d-4417286/ini-sederet-alasan-f-pks-tolak-ruu-penghapusankekerasan-seksual

ELSAM, 12 Oktober 2020, Perkembangan Pembahasan Rancangan Undang-Undang Penghapusan Kekerasan Seksual, https://elsam.or.id/perkembagan-pembahasan-rancangan-undangundang-penghapusan-kekerasan-seksual/

Kompas, 12 Agustus 2020, Kaukus Perempuan Parlemen: Pengesahan RUU PKS Tak Mudah karena Ada Pertarungan Ideologi, https://nasional.kompas.com/read/2020/08/12/11301211/kaukus-perempuan-parlemenpengesahan-ruu-pks-tak-mudah-karena-ada?page=all.

Kompas, 23 Maret 2021, Masuk Prolegnas Prioritas 2021, RUU PDP Tak Hanya soal Kebocoran Data, https://tekno.kompas.com/read/2021/03/23/18020097/masuk-prolegnas-prioritas2021-ruu-pdp-tak-hanya-soal-kebocoran-data.

Kompas, 12 Maret 2021, Revisi UU ITE, Berawal dari Keresahan Jokowi namun Batal Masuk Prolegnas Prioritas 2021, https://nasional.kompas.com/read/2021/03/12/20521121/revisiuu-ite-berawal-dari-keresahan-jokowi-namun-batal-masuk-prolegnas?page=all.

Pikiran Rakyat, 26 Maret 2021, RUU PKS Masuk Daftar Prolegnas 2021, Optimistis Berantas Kekerasan Berbasis Gender Online, https://www.pikiran-rakyat.com/nasional/pr- 
011672755/ruu-pks-masuk-daftar-prolegnas-2021-optimistis-berantas-kekerasan-berbasisgender-online

Republika, 10 Maret 2020, 'Gejayan Memanggil' Menolak Omnibus Law, https://www.republika.id/posts/5039/\%E2\%80\%98gejayan-memanggil\%E2\%80\%99menolak-omnibus-law

SAFEnet, 28 Januari 2019, [Rilis Pers] Kekerasan Berbasis Gender Online (KGBO) Marak, RUU PKS Jangan Sampai Mangkrak, https://id.safenet.or.id/2019/01/kekerasan-berbasis-genderonline-KGBO-marak-ruu-pks-jangan-sampai-mangkrak/

Tardi, S.A., 7 Maret 2021, “Online Grooming Dalam KBGS”, Seminar "Kekerasan Gender Berbasis Online (KGBO) di Era Pandemi”, 30 Tahun Pusat Studi Wanita

Wahyuni, B., 7 Maret 2021, "Tubuhku Bukan Otonomiku”, Seminar "Kekerasan Gender Berbasis Online (KGBO) di Era Pandemi”, 30 Tahun Pusat Studi Wanita 